This article has been scanned by iThenticat No plagiarism detected

Volume 3, Issue 6, December 2021

p. 518-524

\title{
THE COMIC MODE IN KINGSLEY AMIS'S NOVEL"LUCKY JIM"
}

http://dx.doi.org/10.47832/2757-5403.6-3.39

\begin{abstract}
:
During these Study, I realized that the Qur'an is not a book that can be passed over by reading a translation when viewed from the outside. Because it is a book that scholars can't get enough of, that doesn't get old from repetition, and that never ends with admiration. The Quran is a divine and universal institution that teaches people to live with Allah. There cannot be a life that doesn't take God into account; because there is no space or moment without God. In this study, the approach of hermeneutics acquis to the heaven will be examined. According to the meaning of heaven, in the Torah, Psalms, Bible and especially in the Quran, the study will be limited to tafsiri journals. Literature of hermeneutics being tremendous, the impossibility of handling each interpretation yields another limitation. The purpose of writing the study reflects how the names of heaven, which are pictured in the minds with a unique insight in the verses, are handled by Islam.
\end{abstract} Received : 01/11/2021

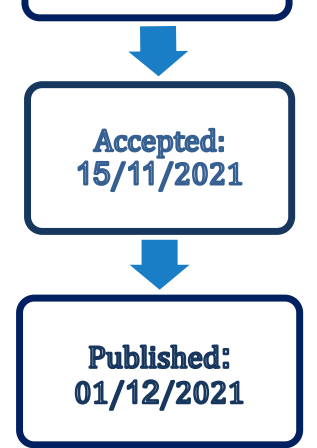

Key words: Comic Mode, Lucky Jim, Comedy, Fiction.

\footnotetext{
${ }^{1}$ Prof.Dr. , Mustansiriyah University, Iraq, eman aldelemi@yahoo.com, https://orcid.org/0000-0003-3849$\underline{1071}$
}

Copyright (C) Published by IJHER Journal, www.ijherjournal.com Rimar Academy, Fatih, Istanbul, 34093 Turkey

All rights reserved 


\section{Introduction:}

The lable 'Angry Young Man', which became current after the presentation of John Osborne 's play Look Back in Anger at the Royal Court Theatre in May 1956, is a roughand-ready one to apply to writers who never presented to form anything approaching a school.But it does signify an attitude of mind which they had common at that stage of their careers.

The 'anger' they displayed was hardly of the kind one associate with D.H Lawerance or with Wyndhan Lewis in the century, or with such great eighteenth-century satirists as Swift and Pope, or with the Elizabethan social filibusters such as Nashe,because what is so clearly implicit in these cases is either a standard of moral reference passionately believed in or the background of a society and culture that still possessed a positive dynamic. The protest of the 'Angry Young Men' was of a far lower voltage, closer to a general dissentience or disgruntlement.It was part social and part cultural.Nearly all of them were too young to have seen war service, and were impatient of the war mystique cherished by their elders; most of them were mildly committed supporters of the Labour Government under whose dispensation some of them had received their educations; many had middle or lower middle class backgrounds; and a number of them were college or university teachers. The main force of their anger was directed not so much against the survivors of the 1930s already discussed as against those who still consistuted a powerful,though outdated Establishment,the liberal-humane,largly upper-middle-class Bloomsbury intelligentsia.( Ford,p: 430)

Lucky Jim remains the most vigorous and effective example of the protest,particularly in the passages that expose the academic racket, and the pseudo-culture and social potensions that so often accompany it-notably in the hilariously funny scenes describing Professor Welch's musical evening and Jim Dixon's public lecture on Merrie England.

Generally speaking the force of the protest tailed after the 1950s.Kingsley Amis continued for a time to direct his anger against a variety of pretensions and hypocrisies. But on the whole his explosions modulated into a consciously satirical mode, accompanied by a chilling but often effective distaste.

Lucky Jim might be considered as a study in life of an antithetical man.Certainly it is enlivened primarily by the fantastic roles and faces that Jim invents for himself in order to offset the horror of his particular Body or Fate: that of a junior lecturer in a repressive university history department headed by a booby distinguished by neither publications nor teaching genius. In face of a badly run,rigid institution which he has found himself dependent, he fantasizes outrageous and hilarious anarchistic retributions against his bureaucratic oppressors.His prime target is the Professor, Welch.( Kennedy, p: 269).

\subsection{Jim's Character:}

He is trapped in a relationship with the insipid Margaret Peel, as he is trapped in his job as lecturer in medieval history that he had chosen as a soft option at school. This relationship continues because of his respect for the conventions of courtship and because of his politeness: he just cannot do anything which hurt Margaret and so their association drags on.If he cannot do anything, he can certainly imagine doing things.

His vicious fantasies are sanctioned as humor partly because he himself is a nice guy who would not really do that sort of thing. i: e he lives by convention because he can find no other adequate way of living. The modes of behaviour which he strives for seem desirable because of the extreme lack of freedom of his present situation,but they would not ,if acted out, fully express the real Jim Dixon. 
The faces that Dixon is always making can be understood because none of which are made when they might be seen by others. These masks of his are a purely private means of release and are not satisfactory 'roles' for use in face-to-face encounters.Jim acts out in private what he would not express in a social situation, and then he finds that he is exposed before another watcher and the result is very comic. His role becomes so convoluted that he must pretend to be doing what he really is doing, waiting to get into the bathroom. With all of his face and private dramas, Jim is attempting to find a ritual means of self-expression which does not derive from the rigid 'roles' offered him by his situation.As he searched for this private means of self-dramatization, he simultaneously denies its validity by obeying the conventional demands of the situation.( Kennedy, p: 270) Amis uses this as a comic device but denies that such a device can become a valid replacement for institutional, publicly validated roles. As Jim later realizes he has not been doing what he really wished to do when he made his faces.

In the conclusion of the novel, one can see that Jim gives up his face -making and his private dramas and is rewarded with a different kind of role, the job of personal secretary to the financier Gore-Urquhart. Jim is perfectly happy with this job, with this public role, but why will life in this job be any different from the one he has had as a lecturer in the redbrick university? Because Urquhart is a better man than Neddy Welch which is to say that the novel is not really an attack on institutionalized roles at all, so much as a critique of the people who fail to fill these roles. There is ample evidence in the novel to indicate that Jim is as much to blame for his discomfort at the college as is the college itself. He is not a fit teacher. so Jim's story is not really that of an 'angry young man' in rebellion against repressive institutions, so much as it is the extremely comic tale of a man in the wrong job. Like so many other writers, Amis is alert to the fact that 'dramatic action' is very important both in life and in art .Instead of exploring all the potentials of dramatic action, however, he is content to grab the laughs and run,turning, in step with Jim himself, to the right.

\subsection{The Comic Mode in the Novel:}

Amis' fiction is marked by an acute comic sense, a finely responsive eye and ear for social nuance, concern about the difficulties of behaving decently, and an intermittent sense of nightmare.

There are those who claim that Amis is not worth anyone's serious attention,that Lucky $\mathrm{Jim}$ is at worst a crude and childish farce, and at best no more than a faded relic of the taste of the early fifties. Nevertheless Lucky Jim remains a comic masterpiece, the funniest English first novel since Antony Powell's Afternoon Men appeared in 1931, and a work that is surpassed only by the very best of Waugh and Powell.

On its first appearance Lucky Jim was assumed to inherit the comic manner of the early Waugh; but some readers also related it to famous work of Edwardian comic fiction, like Well's Kipps or Arnold Bennett's The Card.

Amis has shown himself to be assertively anti-modern,anti-experimental,anti- cosmopolitan ,to at least the same degree as Snow or William Cooper; indeed his tastes are narrower,since he doesnot share Snow's admiration for Proust. Yet his way of writing fiction suggests that he has undergone, no matter how unwillingly, the influence of the Modern Movement, at least in his reliance on linguistic effort; style functions actively in Amis's comic writing, as it does in Powell's.John Gross has remarked on the way in which many of Amis's comic effects originate in his linguistic finesse rather than in the comedy of situation. Throughout his novels there is a steady preoccupation with language (Bergonzi, p: 162).

In Lucky Jim, which remains the most light-hearted and innocent, there are casual references that would seem savage if it were not for the tone and the stylistic controls which preserve it: Jim dreams of stuffing Professor Welch down the lavatory, or of beating him 
about the head and shoulders with a bottle until he explains why he gave his sons French names; at one angry movement he is tempted to push a bead up Margaret Peel's nose. In the latter novels these fantasies of hostility and aggression are more frequent and less controlled.

Nostalgia is also evident, though in a more subdued form.In Lucky Jim the past is regarded as a matter for suspicion:Jim Dixon has no commitment to the history he is supposed to teach, and he loathes Professor Welch's bogus attempts to revive the past by means of handicrafts and madrigal singing.Indeed, when he is forced to give a public lecture on Merrie England, Jim turns it into a virulent hymn of hate against all the more obvious forms of cultural nostalgia.Nevertheless Amis's attachment to a central thread of English in sular nonconformism, and his distaste for cosmopolitan modernism were sufficiently pronounced for Martin Green,in his book A mirror for Anglo-Saxon,to place Amis in a select pantheon representative of the traditional English virtues, the other heroes being Lawerance, Leavis and Orwell. In so far as Amis's basic ideas about novel-writing are traditional, then it is a tradition whose roots lie closer to the eighteenth century then to the high Victorian seriousness admired by Snow or Wilson. (Bergonzi, p: 164).

Lucky Jim is a comic novel,Amis is admirer of Henry Fielding, the first great English comic novelist.It might be profitable therefore to look at Fielding's definition of this form.It deals, he says, in the preface to Joseph Andrews with the Ridiculous, and the only source of the true Ridiculous is affectation, which has two aspects: vanity and hypocrisy.Like most comic literature Fielding's comedy is based on contrast, on incongruity,between,for example,people's actions and their motives. Fielding shows this contrast by commenting on particular situations from his omniscient elevation over the story. The omniscient method, however, is very difficult to employ today, when there are few agreed moral assumptions, and where many people (including Amis) cannot accept the idea of an omniscient God. Although Amis works with contrast,the consciousness which registers them is not the novelist's,but Jim Dixon's. The mind which sees the incongruity of appearance and reality,of what the Welches and Margaret hypocritically or vanity think themselves to besensitive,cultured intellectuals- and what they really are-boring,selfish zombies- this mind is Jim's, and only at a second remove the novelist's.If this were the whole story-if Jim were merely a register of other people's false appearances, Jim might be merely a boorish prig,as many of his literary offspring are;but the saving grace of Amis'novel is that Jim himself is involved in the comedy, he is a hypocrite.Temperament and circumstances impel him to present a false appearance to the world:he pretends to be a keen young scholar and university teacher, when in fact he detests his subject and despises his colleagues; he pretends to be sympathetically attached to Margaret when in fact he finds her plain and tedious. What makes us value Jim above the other shams in the novel is the fact that at least he admits he is a sham, chiefly to himself and that his deceptions can reflect a kind of moral decency as well as a kind of moral cowardice( Lodge, p: 251).

The main source of comedy in the novel is therefore the contrast between Jim's outer world and his inner world. While he tries to show the outer world the image of an industrious, respectable well- mannered young man,his mind seethes with caustic sarcasm directed against himself and others, with fantasies of violence done to enemies, of triumph for himself. So that the characterstic appearance of a page of Aims is an exchange of pedestrian dialogue broken by long paragraphs of densely-woven comic and satirical commentary emanating from the hero's consciousness.The first chapter of Lucky Jim exhibits this pattern.

Jim is well aware of the way his inner life compensates for the unsatisfactory nature of his outer life.His face-pulling,rude gesturing,and practical joking are only an extension of this 
strategy-an attempt on Jim's part to give some physical expression to his inner life of protest.After finishing his hated,hypocritical lecture on 'Merrie England',for instance:

With a long, jabbering belch, Dixon got up from the chair where he'd been writing this and did his ape limitation all around the room. With one arm bent, at the elbow so that the fingers brushed the armpit,the other crooked in the air so that the inside of the forearm lay across the top of his head, he wove with bent kness and hunched, rocking shoulders across to the bed,upon which he jumped up and down a few times, gibbering to himself.A knock at his door was followed so quickly by the entry of Bertrand that he only had time to stop gibbering and straighten his body. (x x).

For most of the action this kind of behaviour remains secret and furtive, and much comedy derives from Jim's attempts to keep it secret.But as long as he does so,he is involved in evasion, compromise, hypocrisy. The issues of the novel can only be resolved when Jim wills his inner life to coincide with his outer life.The crisis comes when he fights Bertrand and knocks him down:

After some seconds, Bertrand began moving about on the floor, but made no attempt to get up.It was clear that Dixon had won this round and,it then seemed, the whole Bertrand match.He put his glasses on again, feeling good;

Bertrand caught his eye with a look of embarrassed recognition The bloody old lower-face boot-faced totempole on a crap-reservation,Dixon thought ,'you bloody old towser-faced boot-faced totem-pole on a crap reservation,' he said ( $\mathrm{x}$ x).

At last thought and speech, the inner and the outer worlds coincide.From this point everything starts to go right for Jim.He loses his job,but gets a better one; he loses his girl (Margaret) but gets a nicer one.Jim ceases to be a guilty hypocrite and reaps his reward.Wecan accept this solution because the comic mode of the novel permits the kind of simplifications that make it possible :that people are as simply nasty as Bertrand will fall down when you hit them, or that their falling down will solve problems( Lodge, p:255).

Amis is in fact involved in a kind of philosophic problem concerning ethics; and his language, which makes subtle discrimination in simple and superficially clumsy prose, often reminds one of modern philosophical discourse.Amis' epistemology, as it manifests itself in his novels, is profoundly antimetaphysical, determinedly positivist, nearly solipsist. Nice things (are) nicer than nasty things), and only the individual can decide what is nice and what is nasty for him .The axiom comes from Lucky Jim (xiv)

Amis has imposed very restrictive limits upon the world of his books by his rejection of the modern mode. These limits are scarcely felt within the simplified comedy of Lucky Jim, but they press hand on the attempt in later novels to incorporate more of the multiplicity of experience. 
Amis' acute awareness, his sardonic sense of the literary tradition and of the limitation of his own stance towards it,and above all his success in finding a language which articulates very exactly the temper of his generation,make him a writer of genuine literary 'importance'. Jim Dixon is a lower-middle class young man half heartedly attempting to adapt to an upper-middle class academic world whose political, social, and aesthetic values he despises.

Although Jim Dixon is aggressively anti-intellectual,he does not leave the university environment to experience a 'real life' job;Amis leaves the nature of his new employment at the end of the novel purposely vague,probably because it will involve Jim with the arty word for which he claims to have so much contempt. Rather than showing his character's need for an idyll of physical labor which will enable him to reenter the outside world, Amis is content with attacking the enclosed society of snobbishness and eccentricity that the university represents.

Jim Dixon, the hero, has an unerring eye for the pretentious for the phony, in institutions, in his colleagues and in himself. He belongs neither to the world of his childhood nor to the new world he inhabits, thanks to his university education and profession.He lives a strange fantasy life, and his frustrations sometimes cause him to be quick off the mark and sometimes a hopeless lout.But fortune favours him: he wins the girl and gets the job for which he has most talent, as a spotter of the phony ( O'Connor, p: 170).

\subsection{Conclusion:}

In the Christmas issue of The Sunday Times, 1955, Somerset Maugham chose Lucky Jim as one of the books of the year. He indicated his respect for its author's talent but he gave his primary attention to the new world Lucky Jim represents and fortells: Lucky Jim is a remarkable novel .It has been greatly praised and widely read, but I have not noticed that any of the reviewers have remarked on its ominous significance. I am told that today rather more than sixty percent of the men who go to the universities go there on a Government grant. This is a new class that has entered upon the scene. It is the white-collar proletariat. Mr. Kingsely Amis is so talented, his observation is so keen, that you cannot fail to be convinced that the young men he so brilliantly describes truly represent the class with which his novel is concerned.

They do not go to the university to acquire culture, but to get a job, and when they have got one, scamp it. They have no manners, and are woefully unable to deal with any social predicament.This idea of a celebration is to go to public house and drink six beers. They are mean, malicious, and envious. They will write anonymous letters to harass a fellow undergraduate and listen in to a telephone conversation that is no business of theirs. Charity, kindliness, generosity, are qualities which they hold in contempt. They are scum. They will in due course leave the university.Some will doubtless sink back, perhaps with relief,into the modest class from which they emerged;some will take to drink, some to crime and go to prison. Others will become school masters and from the young,or journalists and mould public opinion.A few will go to parliament,become Cabinet Ministers and rule the country.I look upon myself as fortunate that I shall not live to see it.( O'Connor, p:172). Maugham has pointed out a significant fact: the cultural life of England is passing to a new class, to those who have gone to the university on their brains and regardless of their origins. 


\section{THE COMIC MODE IN KINGSLEY AMIS'S NOVEL"LUCKY JIM"}

\section{References:}

Bergonzi, Bernard. (1971). The Situation of the Novel. London: Macmillan.

Ford, Boris (ed.) (1983). The New Pelican Guide to English Literature: The Present, vol. 8. Harmondsworth.

Hagu, Angela. (1986).Twentieth Century Literature, vol.32 no 2"Picaresque Structure and the Angry Young Novel".

Kennedy, Alan. (1974). The Procean self: Dramatic Action in Contemporary Novel. London: Macmillan.

Lodge, David.(1966). Language of Fiction: Essays in Criticism and Verbal Analysis of the English Novel.London: Routledge and Kegan Paul .

O' connar.William van. (1962) "Two Types of Heroes in Post-war British Fiction". PMLA, 11. 